\title{
Nanotechnology in 0enology
}

Keywords: Nanomaterials; Wine; Methods; Risks

Abstract

Nanotechnology's era has begun with its broader range of applicability in science and technology. It's stepping into the oenology would be a game changer because of the global wine market. The involvement of nanomaterials from grape to glass has been revolutionary because of the replacement of traditional methods in wine production processes to consume time and ecofriendly approaches in the treatment of winery effluents. But, there is a certain need of changing the consumers and industries perception towards nano wine by raising the nanoscience awareness, improving organoleptic properties and safety assurance.

Recent innovations in nanotechnology has been extending its arms in various fields of science and technology like biotechnology, health, industry, agriculture, energy and environment, transportation, information and electronics. The attenuated nanoscale structures exhibit enhanced electrical, optical and magnetic properties; surface and quantum effects can be utilized to perform specific functions. It is having its impact in several areas of the food industry, including oenology. Nanoparticles are divided into two groups: Non-engineered and engineered. Non-engineered nanoparticles derived from the natural calamities and engineered ones are categorized as follows [1]:

1. Metal oxide nanoparticles from $\mathrm{ATO}, \mathrm{Al}(\mathrm{OH})_{3}, \mathrm{CaO}, \mathrm{CeO}_{2}$, $\mathrm{CuO}, \mathrm{Fe}_{2} \mathrm{O}_{3}, \mathrm{Fe}_{3} \mathrm{O}_{4}, \mathrm{In}_{2} \mathrm{O}_{3}, \mathrm{ITO}, \mathrm{La}_{2} \mathrm{O}_{3}, \mathrm{MgO}, \mathrm{NiO}, \mathrm{SiO}_{2}, \mathrm{TiO}_{2}$ $\mathrm{ZrO}_{2}, \mathrm{ZnO}$

2. Metallic nanoparticles from $\mathrm{Al}, \mathrm{Ag}, \mathrm{Au}, \mathrm{Bi}, \mathrm{Co}, \mathrm{Cu}, \mathrm{Fe}, \mathrm{In}, \mathrm{Mo}$, $\mathrm{Mn}, \mathrm{Ni}, \mathrm{Pd}, \mathrm{Pt}, \mathrm{Si}, \mathrm{Ti}, \mathrm{Zn}$

3. Carbon-based nanomaterials in the form of fullerenes, tubes, fibers, graphene

4. Polymeric nanoparticles are obtained from natural and artificial polymers. Natural polymers are alginate, chitosan, gelatin, cellulose, etc., and synthetic are polyacrylates, polycaprolactone, etc.

5. Dendritic nanoparticles are based on hyperbranched polymers i.e. dendromerseg: poly (amidoamine) PAMAM

6. Quantum dots are made from semiconductor materials such as silicon, cadmium telluride, cadmium selenide etc.

Nanotechnology has gradually started to bring a new global industrial revolution in wine manufacturing technology. According to a recent Zion wine market research report, its value was approximately USD 302.02 billion in 2017 and is expected to be around USD, 423.59 billion by 2023, and a rise at a CAGR of around 5.8\% between 2017 and 2023 [2]. The process of wine making involves mainly harvesting of grapes to crushing, fermentation to maturation of wine, packaging and marketing and nanoscience could be involved from harvesting to packaging phases.

Grapes are the primary source of wine production. Diseases pose major constraints in the production of grapes and can lead to significant reduction in yield and berry composition which thereby affect wine quality. Grapes are attacked mainly by the diseases like anthracnose, downy mildew and powdery mildew and infected by pests such as flea beetle, mealy bugs, thrips, red spider mites, leafhoppers, jassids and stem borers. Nanoparticles can be used as fertilizers, pesticides and fungicides in plant disease management. Conventional methods of fertilizers could be replaced by nano fertilizers as they reduce the frequency of application, increased efficiency of elements and regulatory release of nutrients. Silica, Selenium, Gold, Silver, Copper, Palladium, Manganese, Copper oxide, Zinc oxide, Ferric oxide, Titanium oxide, Hydroxyapatite, nanocomposites consisting of Nitrogen, Phosphorus, Potassium, micronutrients, mannose, amino acids, Zinc-aluminium layered double-hydroxide, nanoporous zeolite have been demonstrated to have the capability to enhance the crop production and increase the availability of nutrients and stress tolerance towards crops [3].

Downy and powdery mildews are the two devastating fungal diseases which can affect both yield and quality of grapes. Khairy reported the application of low molecular nano organic material foliar spray on grapevine cultivar improved plant growth, fruit quality and quantity [4]. Fungicidal activity of silver nanoparticles against Alternaria sp., Botrytis cinerea; copper, chitosan-saponin, chitosan cross-linked with sodium tripolyphosphate and with copper sulphate against Alternaria alternate has been reported. Pheromones are used to trap the undesirable pests which are responsible for yield decrease and crop quality. Nanogelled pheromone, methyl eugenol using a low molecular mass gelator such as all-trans tri (p-phenylenevinylene) bis-aldoxime has been used for trapping the pests in a guava orchard. Nanoencapsulation is the nanotechnological approach consists of active ingredients being protected by a coating which will effectively control pests. Nano-pesticidesas nanoformulations with the combination of surfactants, organic polymers, inorganic metal nanoparticles; iron oxide and gold nanoparticles, amorphous nano silica has been shown their insecticidal activity [3]. The abovementioned application of nanomaterials as fertilizers, fungicides and pesticides on different varieties of cereals, vegetables and fruits could assure us a promising future of grape disease management.

Fermentation of grape juice dominated by yeast strains, mainly Saccharomyces cerevisiae, results in ethanol, carbon dioxide and several other metabolites, is nature's secret behind the wine. This is followed by clarification and stabilization which are important 
processes in vinification, achieved by racking, fining and filtration. In these treatments, the removal of insoluble matter like microbial hazes, excess protein and tartarate, phenolic polymers, residual sugar and malic acid from the wine before bottling makes it clear and stable. Next, wine aging in bottle allows a continuation of slow reactions free of air and highly volatile substances leads to the improvement of wine quality.

Yeast immobilization is defined as the physical confinement of intact cells to a region of space with conservation of biological activity. The immobilization techniques can be mainly categorized into four types: immobilization on solid carrier surfaces, entrapment in a porous matrix, natural aggregation by flocculation and cross-linking by agents or cell containment behind barriers. Multiwalled carbon nanotubes, long thin cylinders of carbon have been used as artificial flocculation agents of yeast cells [5]. The principle behind the flocculation is that the negatively charged live yeast cells are attracted towards positively charged carbon nanotubes results in the separation of yeast cell suspension can be applied in the ethanol industry [6]. Magnetic nanoparticles have been used to separate yeast biomass in sparkling wine bottles. Magnetised yeast have been introduced as magnetic iron oxides, i.e. maghemite $\left(\gamma-\mathrm{Fe}_{2} \mathrm{O}_{3}\right.$ or magnetite $\left(\mathrm{Fe}_{3} \mathrm{O}_{4}\right)$ nanoparticles coated with a thin layer of silica and grafted with APMS. The terminal amino groups of the APMs with the silane groups of silica surface provide a strong positive charge on the surface of nanoparticles and promote their electrostatic adsorption onto the negatively charged surfaces of the cells and the separation is enabled by a magnetic field gradient [7]. These nanoparticles are of low cost and safety assurance was approved by Food and Drug Administration [8-10].

White and blush wines require specific clarification and stabilization treatments compared to red wines. Due to inappropriate storage conditions or tannins enrichment from wood or cork, the insoluble wine proteins get precipitated. This affects the wine clarity and thereby stability. Stable transparency is acquired by the clarification treatment through fining or filtration or both. Fining works on two principles: electrostatic attraction and adsorption. In the wine industry, commonly used wine fining agents are bentonites, saponites, casein, potassium caseinate products, isinglass, egg albumin, gelatin, polyvinyl polypyrrolidone, minerals, wood charcoal, synthetic polymers, enzymes etc. Fining agents used to remove unwanted color, bitterness, astringency, etc. and thus refining the organoleptic characters of wine; in adsorption of proteins and polysaccharides thus conferring wine stability, intoxic and economically feasible. The possible utilization of nanodispersive materials based on $\mathrm{SiO}_{2}, \mathrm{TiO}_{2}$ and $\mathrm{TiO}_{2}-\mathrm{SiO}_{2}$ was reported in white and red wines fining [11]. Mesosporous materials with a porosity between 2 and $50 \mathrm{~nm}$ employ its applications by a broader range of materials include silica, metal oxides, metal hydroxides, metallic salts, carbon structures etc. Mesosporous silica materials have been used as fining agents to remove excess proteins of white wines, reduces volatile acidity and browning index [12].

Nanofiltration can be employed at various steps of vinification such as stabilization, concentration and treatment of winery waste. It is a pressure-driven separation process in which the filtration efficiency depends on sieving and charge. It offers numerous advantages such as high selectivity, less expensive, consumes less energy, can make a combination with the other separation processes to enhance the separation efficiency.
Wine consists of tartaric acid and its salt, potassium bitartrate and calcium tartrate and the solubility of potassium bitartrate decrease by the alcohol formation which results in precipitation of bitartrate crystal deposits in bottled wine stored at low temperatures. So the wine should undergo treatment for tartrate stabilization. Cold stabilization, Westfalia process and electro dialysis are different types of approaches used to prevent tartrate instability. The integration of nano and microfiltration is used for wine concentration and separation of bitartrate salt crystals.

Wine is a complex mixture of water, ethanol, glycerol, carbohydrates, organic acids, tannins, nitrogenous and mineral compounds acquired during vinification. Non-volatile acids as tartaric, malic, succinic acid, citric acids and volatile acids as acetic, formic, propionic acids comprise the total acidity of the wine. Organic acids particularly volatile acids and largely acetic acid contributes $90 \%$ of the volatile acidity interferes with the wine equilibrium and thereby affecting organoleptic characteristics [13]. Nanofiltration is used to reduce the volatile acidity so that the fixed acidity is preserved in wine. It can be used with the integration of ion exchange column or neutralization or electrodialysis [14].

Different methods have been used in vinification process to produce lower alcohol content and retention of bioactive compounds. Grapes contain approximately 20 different anthocyanin compounds are mainly responsible for red wine coloration and quality. Of all these anthocyanins, malvidin-3-glucoside is the most abundant one found in grapes [15]. Resveratrol is a phytoalexin belongs to stilbenes, present in grapes and wine [16]. Two isomeric forms of resveratrol, trans- and cis- have been characterized in wine [17]. Trans-resveratrol has been regarded as the most physiologically active biocompound of red wine than cis- form [18]. Anthocyanins and resveratrol may prevent atherosclerosis and arteriosclerosis and also protect against coronary, Parkinson, Alzheimer, Huntington diseases and some cancer types $[19,20]$. Various technologies, such as traditional thermal process, low- temperature distillation using spinning cone column, and membrane processes have been proposed to reduce the wine ethanol content $[21,22]$. Among the different membrane separation techniques, nanofiltration is one of the best for the partial dealcoholization and concentration of red wine than micro and ultrafiltration membranes [23].

Typical materials that have been used in beverages packaging are glass, metals and plastics capped with metallic or plastic corks and multilayer systems and biopolymers are the advancing approaches towards packaging system. These offer three types of protections to beverages. Physical protection shields beverages from mechanical damage. The limiting factors which affect the shelf-life of food products are gases, water vapour, volatile compounds and sorption process. Studies on chemical reactions during the wine storage have been reported the production of undesirable by-products such as organic acids, aldehydes and ketones can affect the aromatic compounds. Packaging materials can affect the aromatic profile and enological parameters. Chemical protection of beverages is from gases, moisture and light. The incorporation of nanomaterials into the packaging systems could enhance physical and chemical protection and thus prevent the degradation of products. Biological protection is from microorganisms present in wine. The universal wine spoilage 
yeast Brettanomyces bruxellensis occurs ongrapes and also from unhygienic surroundings produce volatile phenols that can confer unpleasant odours will be rejected by consumers [24-26]. Ag, $\mathrm{Cu}$, $\mathrm{Zn}$, Ti based nanoengineered materials are the recent developments in food industry due to their antibacterial and antifungal properties. Silver nanoparticles have been demonstrated to have the ability to efficiently control the B.bruxellensis $[27,28]$.

Detection of contaminants, pathogens or allergens using nanosensors has been considered as the most promising nanotechnological innovation in the beverage industry. Nanosensors can be classified into nanoparticlebased nanosensors, optical and electrochemical nanosensors. Color changes can be observed with the reaction of metal nanoparticles and the analyte in the solution. Electrochemical sensors work on the specific binding of antibodies to a conductive nanomaterial and then the conductivity is measured with the target binding to the antibody. It was shown that the silver nanoparticles and glucose-sensitive enzymes can be used to measure glucose concentrations in commercial beverages [29]. Silver, gold, $\mathrm{Fe}_{3} \mathrm{O}_{4}$ nanoparticles and quantum dots are with good optical properties have been used in optical sensors for the pathogen detection. Optical sensors function on the optical signal change with the activity of nanomaterial and pathogen [30].

Winery waste contains acetic, tartaric, malic, lactic and propionic acids, alcohols, esters, sugars, polyphenols, tannins, lignins, nitrogen and inorganic phosphorus. The high molecular weight compunds and high concentrations of soluble organic acids have been a threat to environment cause water, air and soil pollutions and damage to vegetation. Hence, the winery waste should be treated with the cutting edge technology before releasing into the environment Physicochemical treatments like electrodialysis, reverse osmosis, photo-fentonand ozonation are mostly suitable for large wineries [31]. The aerobic biological systems consist of conventional activated sludge techniques [32,33], sequencing batch reactors [34], activated sludge in jet-loop bioreactors $[35,36]$, rotating biological contractors [37], sequencing batch biofilm reactors [38], fixed bed biofilm reactors [39], membrane bioreactor systems $[40,41]$ and air micro-bubble reactors [42]. The anaerobic biological systems consist of anaerobic filters [43], up-flow anaerobic sludge blanket reactors [44], anaerobic fixed bed reactors and anaerobic sequencing batch biofilm reactors $[45,46]$. Apart from all the above technologies in recent years the application of nanofiltration is increasing rapidly to treat the waste for large wineries. It is used to separate low molecular weight solutes, hardness, dye and heavy metals. For smaller wineries, innovative integrated mobile systems have been introduced with the inclusion of nanomaterials infiltration to accelerate separation process. In these systems, nano composites based on sepiolite and polyDADMAC along with a low charge cationic poly quaternium flocculant which acts as a bridging agent used to effectively remove the suspended solids and turbidity. The increasing concerns about the environment could be well managed by the involvement of nanomaterials in treating the industrial effluents [47].

The introduction of an industrial product into the market is based on purely consumer's perception towards that particular product. In case of wine, the consumer's choice depends on origin of grape variety, taste, price and quality of the wine. The involvement of nanomaterials in different stages of wine production and packaging might negatively affect the consumer due to applied alterations in wine making traditions and environmental consequences. Their perception could be changed positively by reducing the calorie and alcohol content of wine, enhancing the wine quality by improving the production process and thus that might lead to the acceptability by wine industries and consumers.

\section{References}

1. Subbenaik SC (2016) Physical and chemical natures of nanoparticles. In: Kumar CK, Khodakovskaya MV (Eds), Plant nanotechnology: principles and practice. pp. 15-27.

2. (2018) Wine market by colour (Red Wine, Rose Wine, White Wine and Others), by product type and by distribution channel: global industry perspective, comprehensive analysis and forecast, 2017 - 2023, pp. 1-110.

3. Pestovsky YS, Antonio AM (2017) The use of nanoparticles and nanoformulations in agriculture. J of Nanosci Nanotechnol 17: 8699-8730.

4. El-Rahman KH (2017) Effect of nanoorganic materials sustainable control of powdery and downy mildew diseases on yield and quality of grapevines. J Nanomed Nanotechnol 8: 7 (suppl).

5. Connor LO (2009) Innovation in the lab: Emerging material could provide the breakthrough that nanotech needs. Global Res Tech Insights 2: 3.

6. Mamvura TA, Sunny EL, Sibanda V, Clarence SY (2012) Immobilisation of yeast cells on carbon nanotubes. S Afr J Sci 108: 7-8.

7. Berovic M, Berlot M, Kralj S, Makovec D (2014) A new method for the rapid separation of magnetized yeast in sparkling wine. Biochem Eng J 88: 77-84.

8. Nguyen TK (2012) Magnetic nanoparticles: From fabrication to clinical applications, CRC press, Boca Raton, USA, pp. 1- 616.

9. Duguet E, Vasseur S, Mornet S, Devoisselle JM (2006) Magnetic nanoparticles and their applications in medicine. Nanomedicine (Lond) 1: 157-168.

10. Kafayati ME, Raheb J, Angazi MT, Alizadeh S, Bardania H, et al. (2013) The effect of magnetic $\mathrm{Fe}_{3} \mathrm{O}_{4}$ nanoparticles on the growth of genetically manipulated bacterium, Pseudomonas aeruginosa (PTSOX4). Iran J Biotech 11: 41-46.

11. Sachko A, Kobasa I, Moysyura O (2017) Perspectives of utilization of nanodispersive materials based on $\mathrm{SiO}_{2}, \mathrm{TiO}_{2}$ and $\mathrm{SiO}_{2}-\mathrm{TiO}_{2}$ for wine fining $\mathrm{J}$ of Fac of food Eng $16: 216-221$

12. Dumitriu GD, Lerma NL, Cotea VV, Peinado RA (2018) Application of mesosporous materials as fining agents for Pedro ximenez wines. Adv in food Sci Eng 2: 1-29.

13. Amerine MA, Cruess WV (1960) The technology of winemaking, Westport: Connecticut ( $1^{\text {stedn }}$ ) The AVI Publishing Company, UK.

14. Temido JV, Conceicao AC, Geraldes V, BritesAlves AM (2015) Development of a nanofiltration process to remove volatile acidity in wines. Tecnico Lisboa, pp. 1-7.

15. Kelebek H, Canbas A, Selli S, Saucier C, Jourdes M, et al. (2006) Influence of different maceration times on the anthocyanin composition of wines made from vitisvinifera L.,cvs. Bogazkere and Okuzgozii. J of food Eng 77: 10121017.

16. Careri M, Corradini C, Elviri L, Nicoletti I, Zagnoni I (2003) Direct HPLC analysis of quercetin and trans resveratrol in red wine, grape, and winemaking byproducts. J Agric Food Chem 51: 5226-5231.

17. Abril M, Negueruela AI, Perez C, Juan T, Estopanan G (2005) Preliminary study of resveratrol content in Aragon red and rose wines. Food Chem 92: 729-736.

18. Pour-nikfardjam MS, Laszlo G, Dietrich H (2006) Resveratrol-derivatives and antioxidative capacity in wines made from botrytized grapes. Food Chem 96: 74-79.

19. Takacs L, Vatai G, Korany K (2007) Production of alcohol free wine by pervaporation. J of food Eng 78: 118-125. 
20. Saiko P, Szakmary A, Jaeger W, Szekeres T (2008) Resveratrol and its analogs: defense against cancer, coronary disease and neurodegenerative maladies or just a fad? Mutat Res 658: 68-94.

21. Catarino M, Mendes A (2011) Dealcoholizing wine by membrane separation processes. Innov Food Sci Emer Technol 12: 330-337.

22. Liguori L, Russo P, Albanese D, Di Matteo M (2013) Evolution of quality parameters during red wine dealcoholization by osmotic distillation. Food Chem 140: 68-75.

23. Banvolgyi S, Bahceci KS, Vatai G, Bekassy S, Bekassy-Molnar E (2016) Partial dealcoholization of red wine by nanofiltration and its effect on anthocyanin and resveratrol. Food Sci and Technol Int 22: 677-687.

24. Di Toro MR, Capozzi V, Beneduce L, Alexandre H, Tristezza M, et al. (2015) Intraspecific biodiversity and 'spoilage potential' of Brettanomyces bruxellensis in Apulian wines. LWT-Food Sci Technol.

25. Srinivasan K, Kumaravel S (2015) A comparative study: The impact of solven extraction on phytochemical profiling of Adhatodavasica. Int J Pharma Res Health Sci 3: 874 - 879

26. Capozzi V, Di Toro MR, Grieco F, Michelotti V, Salma M, et al. (2016) Viable but not culturable (VBNC) state of Brettanomyces bruxellensis in wine: New insights in molecular basis of VBNC behavior using a transcriptional approach. Food Microbiol 59: 196-204.

27. Marsh K, Bugusu B (2007) Food packaging-roles, materials, and environmental issues. J Food Sci 72: R39-55.

28. Ramos M, Valdes A, Mellinas AC, Garrigos MC (2015) New trends in beverage packaging systems: A review. Beverages 1: 248-272.

29. Ozdemir C, Yeni F, Odaci D, Timur S (2010) Electrochemical glucose biosensing by pyranose oxidase immobilized in gold nanoparticle-polyaniline/ $\mathrm{AgCl} /$ gelatin nanocomposite matrix. Food Chem 119: 380-385.

30. Potyrailo AR, Nagraj N, Tang Z, Mondello FJ, Surman C, et al. (2012) Battery free radio frequency identification (RFID) sensors for food quality and safety. J Agric Food Chem 60: 8535-8543.

31. Mosse K,Patti AF, Christen EW, Cavagnaro TR (2011) Review: Winery waste water quality and treatment options in Australia. Aust J Grape Wine Res 17 111-122.

32. Fumi MD, Parodi G, Parodi E, Silva A, Marchetti R (1995) Optimization of long-term activated sludge treatment of winery waste. Bioresource Technology 52: 45-51

33. Brucculeri M, Bolzonella D, Battistoni P, Cecchi F (2005) Treatment of mixed municipal and winery wastewaters in a conventional activated sludge process: A case study. Water Sci Technol 51: 89-98.
34. Torrijos M, Moletta R (1997) Winery wastewater depollution by sequencing batch reactor. Water Sci Technol 35: 249-257.

35. Petruccioli M, Duarte JC, Eusebio A, Federici F (2002) Aerobic treatment of winery wastewater using a jet-loop activated sludge reactor. process Biochem 37: 821-829.

36. Eusébio A, Petruccioli M, Lageiro M, Federici M, Duarte JC (2004) Microbial characterization of activated sludge in jet-loop bioreactors treating winery wastewaters. J Ind Microbiol Biotechnol 31: 29-34.

37. Malandra L, Wolfaardt G, Zietsman A, Viljoen-Bloom M (2003) Microbiology of a biological contactor for winery waste water treatment. Water Res 37 : 4125-4134

38. Andreottola G, Foladori P, Ragazzi M, Villa R (2002) Treatment of winery wastewater in a sequencing batch biofilm reactor. Water Sci Technol 45: 347354.

39. Andreottola G, Foladori P, Nardelli P, Denicolo A (2005) Treatment of winery wastewater in a full scale fixed bed biofilm reactor. Water Sci Technol 51 71-79.

40. Artiga P, Carballa M, Garrido JM, Mendez R (2007) Treatment of winery wastewater in a membrane submerged bioreactor. Water Sci Technol 56: 63-69.

41. Valderrama C, Ribera G, Bahi N, Llado XM, Rovira M, et al. (2012) Winery wastewater treatment for water reuse purpose: conventional activated sludge versus membrane bioreactor (MBR). 306: 1-7.

42. Oliveira M, Queda C, Duarte E (2009) Aerobic treatment of winery wastewater with the aim of water reuse. Water Sci Technol 60: 1217-1223.

43. Yu HQ, Zhao QB, Tang Y (2006) Anaerobic treatment of winery wastewate using laboratoy-scale multi- and single-fed filters at ambient temperatures. Process Biochem 41: 2477-2481.

44. Keyser M, Witthuhn RC, Ronquest LC, Britz TJ (2003) Treatment of winery effluent with upflow anaerobic sludge blanket (UASB)-- granular sludges enriched with Enterobacter sakazakii. Biotechnol Lett 25: 1893-1898.

45. Ganesh R, Rajinikanth R, Thanikal JV, Ramanujam RA, Torrijos M (2010) Anaerobic treatment of winery wastewater in fixed bed reactors. Bioprocess Biosyst Eng 33: 619-628.

46. Ruiz C, Torrijos M, Sousbie P, Lebrato-Martinez J, Moletta R, et al. (2002) Treatment of winery wastewater by anaerobic sequencing batch reactor. Water Sci Technol 45: 219-224

47. Litaor MI, Meir-Dinar N, Castro B, Azaizeh H, Rytwo G, et al. (2015) Treatment of winery wastewater with aerated cells mobile system. Environ Nanotechnol Monit Manag 4: 17-26. 